University of Nebraska - Lincoln

DigitalCommons@University of Nebraska - Lincoln

Nebraska Cooperative Fish \& Wildlife Research Nebraska Cooperative Fish \& Wildlife Research Unit -- Staff Publications

2008

\title{
A Simple Model for Predicting Survival of Angler-Caught and Released Largemouth Bass
}

Gene R. Wilde

Texas Tech University, gene.wilde@ttu.edu

Kevin L. Pope

University of Nebraska-Lincoln, kpope2@unl.edu

Follow this and additional works at: https://digitalcommons.unl.edu/ncfwrustaff

Part of the Other Environmental Sciences Commons

Wilde, Gene R. and Pope, Kevin L., "A Simple Model for Predicting Survival of Angler-Caught and Released Largemouth Bass" (2008). Nebraska Cooperative Fish \& Wildlife Research Unit -- Staff Publications. 85. https://digitalcommons.unl.edu/ncfwrustaff/85

This Article is brought to you for free and open access by the Nebraska Cooperative Fish \& Wildlife Research Unit at DigitalCommons@University of Nebraska - Lincoln. It has been accepted for inclusion in Nebraska Cooperative Fish \& Wildlife Research Unit -- Staff Publications by an authorized administrator of DigitalCommons@University of Nebraska - Lincoln. 


\title{
A Simple Model for Predicting Survival of Angler-Caught and Released Largemouth Bass
}

\author{
Gene R. Wilde**1 and Kevin L. Pope ${ }^{2}$ \\ Wildlife and Fisheries Management Institute, Texas Tech University, \\ Mail Stop 2125, Lubbock, Texas 79409, USA
}

\begin{abstract}
We conducted a controlled experiment in the laboratory to assess the influence of anatomical hooking location and water temperature on survival of angler-caught and released largemouth bass Micropterus salmoides. Survival was $98 \%$ (58 of 59 fish) among fish that were hand-hooked within the oral cavity (including the gills), whereas survival was 66\% (33 of $50 \mathrm{fish}$ ) among fish that were hand-hooked in the esophagus. Survival of hooked fish was not significantly influenced by water temperature $\left(7-27^{\circ} \mathrm{C}\right)$ or the hooking location $\times$ water temperature interaction. We combined our results with prior research to develop a predictive model of largemouth bass survival, which was $98.3 \%(\mathrm{SD}=1.87 \%)$ for fish hooked in the oral cavity and $55.0 \%(\mathrm{SD}=9.70 \%)$ for fish hooked in the esophagus. The model is valid for water temperatures ranging from $7{ }^{\circ} \mathrm{C}$ to $27^{\circ} \mathrm{C}$ and allows one to estimate, with known precision, the survival of angler-caught and released largemouth bass without the need for controlled studies or for holding fish in pens or cages to assess delayed mortality.
\end{abstract}

Recreational anglers commonly capture and release fish (USFWS and USCB 2002; Roy Morgan Research 2003), either as part of a catch-and-release ethic or because of regulatory requirements. In many fisheries, a substantial portion of the fish population may be captured and released (Schill et al. 1986; Nuhfer and Alexander 1992; Davis 2002). Consequently, survival of released fish can have a major impact on fishery quality. Because of the prevalence and fishery importance of catch-and-release fishing, a substantial body of literature has emerged that relates survival to bait type (including live and artificial baits), bait size, number and size of hooks, presence of barbs, anatomical hooking location within the mouth, depth of capture, angler handling and release techniques, and environmental conditions (Taylor and White 1992; Muoneke and Childress 1994; Wilde 1998; Wilde et al. 2000; Davis 2002; Bartholomew and Bohnsack 2005). Despite the proliferation of catch-and-release survival studies, substantial knowledge gaps persist because conclusions from individual studies seldom are consistent. Additionally, most studies of fish survival examine only a single factor, such as hook type or lure type. Those studies that examine more than one factor have been conducted in the field where seasonal

\footnotetext{
* Corresponding author: gene.wilde@ttu.edu

${ }^{1}$ Present address: Department of Biological Sciences, Texas Tech University, Lubbock, Texas 79409, USA.

${ }^{2}$ Present address: U.S. Geological Survey, Nebraska Cooperative Fish and Wildlife Research Unit, University of Nebraska, Lincoln, Nebraska 68583, USA.
}

Received December 14, 2006; accepted October 10, 2007 Published online April 24, 2008 variation in water temperature or other environmental conditions affect fish behavior and physiology and, consequently, survival estimates. Relatively few studies involve designed, controlled experiments. Further, because there is no standard protocol for conducting studies of released fish survival, multiple survival estimates for a given species make it difficult to determine which estimates, if any, are reliable and which should be used to assess potential fishery impacts. Variations in protocol include the mortality observation period, presence or absence of control fish, and holding environments or conditions.

The difficulty in reconciling results from studies with differing protocols is illustrated in Table 1 by a summary of survival estimates for largemouth bass Micropterus salmoides; these estimates range from $62 \%$ to $100 \%$. Some of the studies included experimental controls, whereas others did not. Three of the estimates are less than the $80 \%$ survival rate that Muoneke and Childress (1994) suggested was necessary to prevent fishery impacts in most fish stocks. Depending on which results are consulted, survival rates may be high enough that catch and release poses no fishery risk or may be low enough to affect fishery quality. It is difficult to determine which survival rates should be used to assess potential fishery impacts. There is similar variation among survival estimates for caught and released fish of other species, and this variation presents similar problems for fishery scientists.

Systematic laboratory experiments are more likely to uncover patterns and generalities of fish survival than can be recognized through study of random combinations of risk factors in field experiments (Davis 2002). 
TABLE 1.-Survival estimates from seven studies of largemouth bass caught and released by anglers. Use of control fish in each study is indicated.

\begin{tabular}{|c|c|c|c|}
\hline $\begin{array}{c}\text { Survival } \\
(\%)\end{array}$ & $\begin{array}{c}\text { Control } \\
\text { fish }\end{array}$ & $\begin{array}{c}\text { Water } \\
\text { temperature } \\
\text { or month }\end{array}$ & Source \\
\hline 61.7 & No & Apr-Oct & Rutledge and Pritchard (1977) \\
\hline 75.0 & Yes & Unspecified & May (1973) \\
\hline 77.9 & No & $31-33^{\circ} \mathrm{C}$ & Myers and Poarch (2000) \\
\hline 90.8 & Yes & $9-15^{\circ} \mathrm{C}$ & Pelzman (1978) \\
\hline 96.6 & Yes & Oct-Jun & Mankin et al. (1984) \\
\hline 97.8 & No & $11-33^{\circ} \mathrm{C}$ & Plumb et al. (1988) \\
\hline 100.0 & Yes & $15-31^{\circ} \mathrm{C}$ & Pope and Wilde (2004) \\
\hline
\end{tabular}

It appears that the two most important factors influencing survival of largemouth bass that are captured and released by anglers are the anatomical hooking location (e.g., oral cavity, gills, or esophagus; Pelzman 1978; Weidlein 1987; Muoneke and Childress 1994; Bartholomew and Bohnsack 2005; James et al. 2007) and water temperature (e.g., Wilde 1998). Therefore, we conducted a controlled experiment in the laboratory to measure the effects of these variables on survival of caught and released largemouth bass. We then used our results to develop a model to predict survival of angler-caught and released largemouth bass as influenced by anatomical hooking location and water temperature. Our experiments specifically tested three null hypotheses: (1) fish survival is independent of anatomical hooking location; (2) fish survival is independent of water temperature; and (3) the effects of anatomical hooking location and water temperature on survival are additive (i.e., there is no significant interaction effect).

\section{Methods}

Experimental hooking trials.-Largemouth bass (standard length $[\mathrm{SL}]=155-352 \mathrm{~mm}$; weight $=76-$ $883 \mathrm{~g}$ ) were collected with electrofishing (pulsed DC) using a boat equipped with a Smith-Root 5.0 generatorpowered pulsator electrofisher. We conducted two separate trials in this experiment. For the first trial, 96 fish were captured from Lake Alan Henry (Garza County, Texas) on 21 May 2003. For the second trial, 78 fish were captured from Lake Alan Henry on 6 April 2004 and 18 fish were captured from the Aught-Four Ranch (Gray County, Texas) on 13 April 2004. Source populations were admixtures of two subspecies, the northern largemouth bass $M$. salmoides salmoides and Florida largemouth bass $M$. salmoides floridanus. For both trials, fish were transported in aerated hauling tanks to Texas Tech University, Lubbock, and held for 1 week. Fish were then anesthetized with tricaine methanesulfonate (MS-222) at a concentration of $0.1 \mathrm{~g} / \mathrm{L}$ of water, implanted with passive integrative transponder (PIT) tags (following Prentice et al. 1993), measured for SL $(\mathrm{mm})$, weighed $(\mathrm{g})$, and placed randomly into one of three 852-L, rectangular tanks (183-cm length; 71-cm width; 66-cm depth) to provide similar size distributions within each tank. Water temperatures were increased or decreased daily by $1^{\circ} \mathrm{C}$ until the randomly assigned treatment temperature for each tank was reached. Treatment water temperatures were 7,17 , and $27^{\circ} \mathrm{C}$ in the first trial and 14,24 , and $34^{\circ} \mathrm{C}$ in the second trial. After desired water temperatures were reached, largemouth bass were allowed to acclimate to the tanks for at least $21 \mathrm{~d}$. Fish were fed every $1-4 \mathrm{~d}$ depending on how quickly they consumed introduced prey (sunfishes Lepomis, cyprinid minnows, gizzard shad Dorosoma cepedianum, plains killifish Fundulus zebrinus, inland silversides Menidia beryllina, and western mosquitofish Gambusia affinis). About $20 \%$ of the water in each experimental aquarium was replaced daily to maintain water quality, and aeration was supplied to each tank through air stones.

Our laboratory experiment was designed to simulate catch-and-release fishing. Individual largemouth bass, identifiable by their PIT tags, were assigned to one of three hooking treatments: control, oral cavity hooking, or esophagus hooking. Hooking treatments were randomly assigned to each PIT tag number. To apply treatments, we crowded fish in each tank into one end of the tank using a block net. We captured fish by dip net and scanned them with a PIT-tag reader to identify individual fish and assign them to the predetermined hooking treatments. To simulate angling, fish were hand-hooked with a $2 / 0$ barbed worm hook. For gillhooked fish, the hook was applied to the posterior side of the gill arch. Actual site of gill penetration varied among fish and included the arch itself, the gill lamellae, and in one instance the inner operculum. Handling time (including the hooking procedure) ranged from 15 to $85 \mathrm{~s}$ (mean $=32.0 \mathrm{~s}, \mathrm{SD}=12.5 \mathrm{~s})$ and was protracted for a small number of fish because of the extra time needed to identify the pre-assigned treatment. Largemouth bass were returned to the tank on the opposite side of the block net and were played using a 1.2-m, medium-action rod with 3.6-kg-test monofilament line. Each fish was played until it could easily be landed by grasping the lower jaw. Playing time ranged from 31 to $107 \mathrm{~s}$ (mean $=58.0 \mathrm{~s}, \mathrm{SD}=$ $16.2 \mathrm{~s}$ ). Captured fish were taken from the water, the hook was removed using needlenose pliers, and each fish was released back into its original tank. Hook removal time ranged from 0 to $166 \mathrm{~s}$ (mean $=80 \mathrm{~s}, \mathrm{SD}$ $=28 \mathrm{~s}$ ). To control for effects attributable to the handhooking process, we included control fish that were handled in an identical manner up to the point of hook 
penetration. Control fish were given a sham hooking, in which a hook with the tip removed was touched to the preselected hooking site without inflicting a hooking wound; these fish were then released back into the tank of capture. After the hooking treatment, largemouth bass were held in tanks, fed, and allowed to recover from angling. Dead fish were removed from tanks each day and were identified by PIT tags. For catch-and-release survival studies, 2-d (Cooke and Hogle 2000; Taylor et al. 2001) and 3-d (Nelson 1998; Dunmall et al. 2001; Edwards et al. 2004; Stunz and McKee 2006) observation periods are common. We observed control and experimental fish for $3 \mathrm{~d}$ to assess catch-and-release survival of largemouth bass, and thus our model was for 3-d survival. However, we maintained and observed fish for an additional $3 \mathrm{~d}$ (total $=6 \mathrm{~d}$ ) based on the 6-d period recommended by Wilde (1998) for estimates of tournament-associated mortality.

Statistical design and analysis.-Based on the size of the experimental tanks, we chose a sample size of 32 fish/tank (density $=1 \mathrm{fish} / 26.6 \mathrm{~L})$ for each temperature treatment: 10 control fish, 10 esophagus-hooked fish, and 12 mouth-hooked fish. Hook placement in the esophagus was stratified so that the hook was oriented dorsally in five randomly selected fish and ventrally in the remaining five; hook placement in the mouth included 38 possible regions assigned randomly without region exclusion (i.e., once a region was selected, it was not excluded for the next fish; Figure 1). Because Pelzman (1978) found no difference in survival between fish hooked in the mouth versus the gills, all locations within the oral cavity, including the gills, were considered to constitute a single treatment, but we used additional fish in the oral hooking treatment to examine possible survival variation among the 38 hooking locations.

We used S-Plus version 6.1 (Insightful Corporation, Seattle, Washington) to develop a generalized linear model (log link and binomial error structure) that related survival to temperature and anatomical hooking location. We initially assessed whether there was a difference in survival between the first and second trials. There was no evidence of any difference in survival between the two trials (chi-square test statistic $\chi^{2}=0.3425, \mathrm{df}=1, P=0.5578$ ), so we pooled the results. The final analysis considered two hooking treatments (oral cavity and esophagus), five temperatures (treated as a continuous covariate), and the interaction between these two factors. Thus, our estimates of survival based on hooking treatment had a large effective sample size ( $\mathrm{df}=1$ for hooking location, 1 for water temperature, and 1 for the hooking location $\times$ temperature interaction, and 157 for model

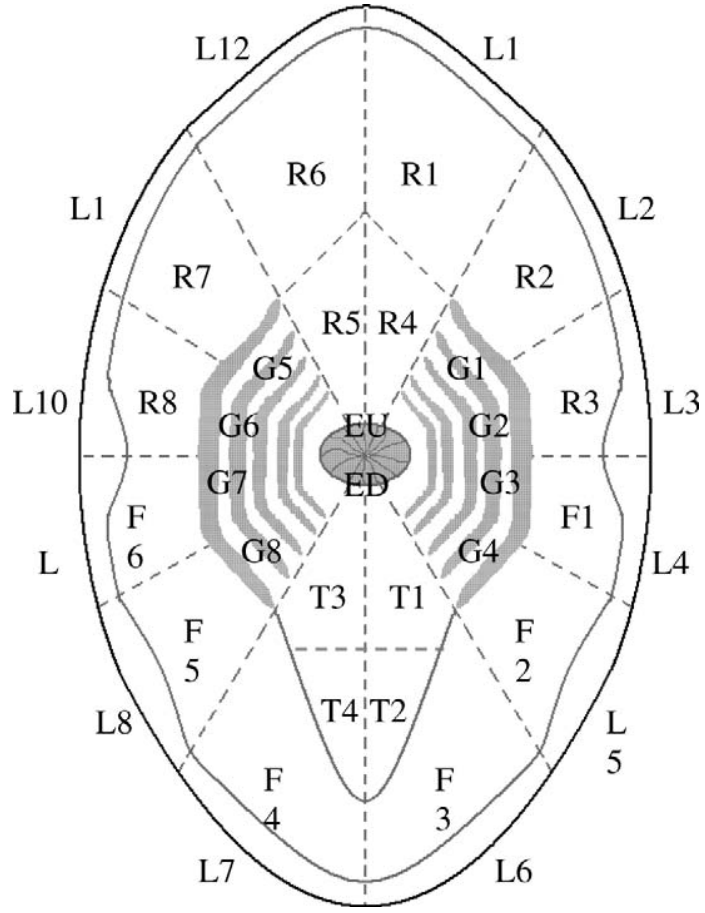

FIGURE 1.-Diagram of a largemouth bass mouth (modified slightly from Pelzman 1978), identifying the 40 possible oral hooking regions examined in a laboratory study of the effects of hooking location on postrelease survival (EU $=$ upper esophagus, ED = lower esophagus, G1-G8 = gill arch, R1-R8 $=$ roof of mouth, T1-T4 = tongue, F1-F6 = floor of mouth, and $\mathrm{L} 1-\mathrm{L} 12=$ lip).

error). We used a chi-square homogeneity test to assess potential differences in survival based on hook orientation in the esophagus (dorsal versus ventral). We used generalized linear models to assess the potential effects of handling time, playing time, hook removal time, and fish size on survival.

\section{Results}

The target sample size of 32 largemouth bass/tank was obtained for each of the $7,14,17$, and $27^{\circ} \mathrm{C}$ temperature treatments. In the $24^{\circ} \mathrm{C}$ treatment, 9 control fish, 11 mouth-hooked fish, and 10 esophagus-hooked fish were used because 2 fish died during the acclimation period. In the $34^{\circ} \mathrm{C}$ tank, all fish became noticeably ill before completion of acclimation and were euthanized.

There was no relationship between largemouth bass survival and handling time $\left(\chi^{2}=0.1033, \mathrm{df}=1, P=\right.$ $0.7944)$, playing time $\left(\chi^{2}=0.3199\right.$, df $=1, P=$ $0.5716)$, or hook removal time $\left(\chi^{2}=1.2336, \mathrm{df}=1, P\right.$ $=0.2667$ ). Although survival was inversely related to length $\left(\chi^{2}=5.0533\right.$, $\left.\mathrm{df}=1, P=0.0246\right)$ and mass 


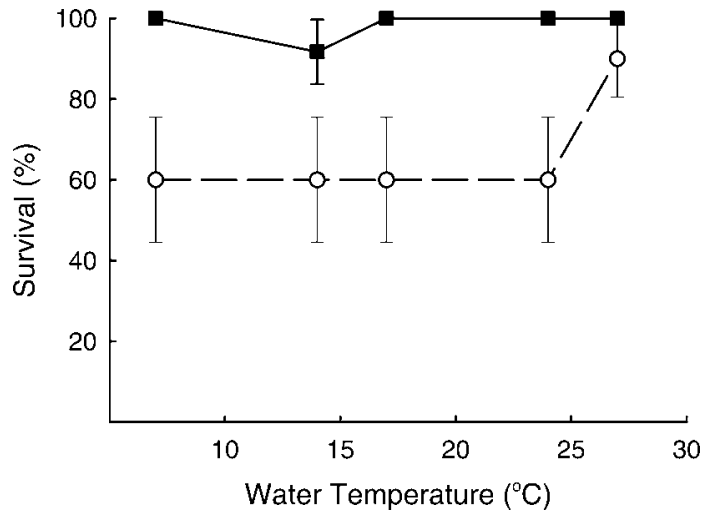

FIGURE 2.-Laboratory-based mean ( \pm SE) survival in relation to water temperature $\left(7-27^{\circ} \mathrm{C}\right)$ for largemouth bass that were hand-hooked in the oral cavity (including the gills; black squares) or in the esophagus (white circles).

$\left(\chi^{2}=4.9254, \mathrm{df}=1, P=0.0265\right)$, inspection of residual plots and other regression diagnostics led us to conclude that these relationships were an artifact of the randomization procedures used in our experimental design. Therefore, we did not include length or mass in our model.

All 49 control fish survived the sham hooking and experimental handling, so our survival estimates for captured and released fish did not require adjustment for losses of control fish (e.g., Wilde et al. 2003b). Therefore, we can attribute all observed mortality among hooked largemouth bass to hooking, playing, hook removal, and release. Overall, $89 \%$ (140 of 158) of the fish that received a hooking treatment survived capture and release. Of the 18 fish that died, 14 died within $3 \mathrm{~h}$ of release and 4 died within $48 \mathrm{~h}$ of release. Only one fish (hooked in the esophagus) died between the third and sixth days, but this fish was treated as a survivor because it was alive at the end of the initial 3-d observation period. Among largemouth bass that were hooked within the oral cavity, including the gills, $98 \%$ (58 of 59 fish) survived. The sole mortality was observed in a fish hooked in the floor of the mouth. Therefore, we have no evidence that survival was affected by the precise hooking region within the oral cavity. Survival was $66 \%$ (33 of 50 fish) among fish hooked in the esophagus. This rate is significantly lower $\left(\chi^{2}=20.49, \mathrm{df}=1, P<0.0001\right)$ than survival observed among fish hooked in the oral cavity. Thus, we rejected null hypothesis 1 . For fish hooked in the esophagus, survival was greater $\left(\chi^{2}=8.64, \mathrm{df}=1, P=\right.$ 0.0033 ) among those hooked dorsally (survival $=83 \%$; 24 of 29 fish) than among those hooked ventrally (43\%; 9 of 21 fish). We expected greater mortality among the ventrally hooked group because of the heart's proximity to the ventral portion of the esophagus.

Across the range of temperatures used in our trials $\left(7-27^{\circ} \mathrm{C}\right)$, there was no significant effect of temperature on survival $\left(\chi^{2}=0.078, \mathrm{df}=1, P=0.7800\right.$; Figure 2$)$. Thus, we failed to reject null hypothesis 2 . Combining all anatomical hooking locations (oral cavity and esophagus), survival ranged from $84 \%\left(14^{\circ} \mathrm{C}\right)$ to $97 \%$ $\left(24^{\circ} \mathrm{C}\right)$.

There was no significant hooking location $x$ temperature interaction effect on survival $\left(\chi^{2}=0.793\right.$, $\mathrm{df}=1, P=0.7783$ ). Thus, we failed to reject null hypothesis 3 .

\section{Discussion}

Despite the large number of studies that have examined survival of angler-caught fish (Muoneke and Childress 1994; Bartholomew and Bohnsack 2005), ours is the first controlled experiment designed to simultaneously study two survival predictors and their potential interaction. Our results build on and extend those of Pelzman (1978), who conducted experiments over a period of several months at temperatures of $9-15^{\circ} \mathrm{C}$. Our experiment demonstrates that the temperature range over which Pelzman (1978) conducted his trials has no effect on largemouth bass survival and, furthermore, that his results are consistent with those for fish captured and released at temperatures as high as $27^{\circ} \mathrm{C}$. Therefore, we combined the results of the two studies to estimate survival of released largemouth bass as $98.3 \%$ ( $\mathrm{SD}=1.87 \%$ ) for fish hooked in the oral cavity and $55.0 \%(\mathrm{SD}=9.70 \%)$ for fish hooked in the esophagus.

These relationships are valid across water temperatures from $7^{\circ} \mathrm{C}$ to $27^{\circ} \mathrm{C}$ and allow one to estimate, with known precision, the survival of caught and released largemouth bass without the need for controlled studies or for holding fish in pens or cages to assess delayed mortality. Thus, after a largemouth bass is captured and the hooking location is recorded, an estimate of survival and its standard error can be derived from the relationships above. Similar models for survival of angler-caught fish based on anatomical hooking location were constructed by Nuhfer and Alexander (1992) for trophy-sized brook trout Salvelinus fontinalis and by Lindsay et al. (2004) for Chinook salmon Oncorhynchus tshawytscha. However, these models did not assess potential temperature effects on survival. Further, because these models were based on field observations, they do not allow for any assessment of joint effects of anatomical hooking location and other survival predictors (Davis 2002).

We observed that death due to capture and release, when it occurred, generally was rapid. Among fish that 
died from hooking, playing, hook removal, and release, most died within $3 \mathrm{~h}$ of release. This is consistent with the observations of Pelzman (1978), who found that $62.5 \%$ (20 of 32) of hand-hooked largemouth bass died within $24 \mathrm{~h}$ postrelease and that $66.7 \%$ ( 8 of 12) of fish that died after $24 \mathrm{~h}$ postrelease were hooked in the esophagus. In our experiment, all largemouth bass that died after $3 \mathrm{~h}$ postrelease were hooked in the esophagus. We believe that a 3-d observation period is sufficient for survival assessments of largemouth bass that are caught and released by anglers, as only one fish in our experiment died between 3 and $6 \mathrm{~d}$ postrelease. Including this mortality event in our results would have had little effect $(<1 \%)$ on our model estimate of survival for fish hooked in the esophagus.

Catch and release appears to have little negative effect on orally hooked largemouth bass across a wide range of water temperatures $\left(7-27^{\circ} \mathrm{C}\right)$. Survival is high among largemouth bass hooked in the oral cavity (Pelzman 1978: 99\%; Pope and Wilde 2004: 100\%), and catch and release has no negative effect on growth of fish hooked in this location (Pope and Wilde 2004). Survival of largemouth bass hooked in the esophagus is much lower, and no assessment of growth is available for captured and released largemouth bass hooked in the esophagus. The proportion of angler-caught largemouth bass that are hooked in the esophagus is unknown but presumably varies among baits. For example, $0 \%$ of largemouth bass captured with plastic grubs were hooked in the esophagus (Pope and Wilde 2004), whereas $18 \%$ of fish captured with a Carolinarigged plastic worms were hooked in the esophagus (Myers and Poarch 2002). An understanding of angler behavior and use of various baits and the relative vulnerability of largemouth bass to capture with those baits is needed to determine the proportion of captured fish that might be hooked in the esophagus and hence subjected to a low survival rate. Because anglers use different gears in different ways throughout the year (e.g., Pope and Willis 1996), we would expect to observe seasonal variation in survival of angler-caught largemouth bass. It is possible that hooking survival in a field study could appear to be related to water temperature (e.g., Wilde 1998) when in fact the observed differences in survival are attributable to seasonal variation in the proportion of esophagushooked fish.

Our results allow us to reconcile the disparate estimates available for survival of captured and released largemouth bass (Table 1). Among the lowest survival estimates are those of Rutledge and Pritchard (1977; 61.7\%) and Myers and Poarch (2002; 77.9\%; Table 1). Both studies failed to include adequate controls. Consequently, excessive mortality attributable to extraneous factors cannot be eliminated as a possible explanation for the low survival estimates reported by these authors. Descriptions of the populations studied and holding conditions lead us to conclude that unassessed risk factors are probably responsible for the low survival they observed. In a hooking study of largemouth bass, May (1973) observed $75.0 \%$ overall survival among 20 hooked fish: $13(92.9 \%)$ of 14 orally hooked fish and 2 (33.3\%) of 6 esophagushooked fish survived (5 of 5 control fish also survived). Application of our survival rates for esophagus-hooked (55.0\%) and mouth-hooked $(98.3 \%)$ fish to the respective numbers of fish tested by May (1973) produced an overall survival rate of $85.3 \%$ (i.e., $\{[0.550 \times 6]+[0.983 \times 14]\} / 20)$. For all 335 largemouth bass assessed by Pelzman (1978), including the 50 controls, 302 (90.1\%) survived. The hooking locations for the 285 hand-hooked fish were predetermined by Pelzman's experimental design; 22 (44\%) of the 50 esophagus-hooked fish survived, and 231 (98\%) of the 235 orally hooked fish survived. Of the 50 control fish, 49 (98\%) survived. Finally, the other estimates of survival (Table 1), which range from $96.6 \%$ to $100 \%$, are consistent with our experimental estimates for fish hooked in the oral cavity. Except for two uncontrolled studies (Rutledge and Pritchard 1977; Myers and Poarch 2002), the available estimates in Table 1 are generally consistent with our model predictions, thus providing initial validation of our model. All available evidence suggests that survival is high among largemouth bass hooked in the oral cavity and is substantially lower among those hooked in the esophagus.

Our results have implications for understanding survival of black basses Micropterus spp. that are captured and released in fishing tournaments. On average, $72 \%$ of tournament-caught black bass survive capture, holding in live wells, handling at weigh-in, and release, and this survival rate is inversely related to water temperature (Wilde 1998). However, our experimental results and model suggest that water temperature within the range examined by most black bass tournament assessments has no effect on survival of captured and immediately released largemouth bass (Wilde 1998). Therefore, the documented relationship between survival of tournament-caught black bass and water temperature must be attributable to live-well confinement, handling during weigh-in, or both. Livewell confinement might subject fish to stressors such as deficient dissolved oxygen, accumulated metabolic wastes, crowding, and elevated rates of activity (Hartley and Moring 1993; Kwak and Henry 1995; Cooke et al. 2002; Suski et al. 2005). In addition, air exposure during conventional weigh-in has been 
identified as a main cause of physiological disturbance in largemouth bass and walleyes Sander vitreus (Suski et al. 2004; Killen et al. 2006), and there is evidence that the degree of the physiological disturbance in largemouth bass is related to air temperature.

Although our model of largemouth bass survival after catch and release provides greater understanding of this issue, gaps in our knowledge persist. First, our model is only useful for the water temperature range of $7-27^{\circ} \mathrm{C}$. Survival may be affected by heat-related stress at greater temperatures. Second, Taylor et al. (2001) found that survival of captured and released common snook Centropomus undecimalis was $83 \%$ for esophagus-hooked fish, $93 \%$ for foul-hooked fish (i.e., those hooked anywhere external to the oral cavity), and $99 \%$ for orally hooked fish (i.e., other than those hooked in the esophagus and stomach). Similarly, James et al. (2007) reported 92\% survival for foul-hooked spotted seatrout Cynoscion nebulosus. No previous study has assessed survival of foul-hooked largemouth bass, although foul-hooking of this species on artificial lures is common, and the incidence of foul-hooking appears to be correlated with the number of hooks on the lure (e.g., Wilde et al. 2003a). Survival might be reduced in foul-hooked fish if hooks penetrate the external musculature and damage internal organs, such as the heart or liver (e.g., Hulbert and Engstrom-Heg 1980; Diggles and Ernst 1997). Third, our results are specific to fish captured with single-barbed $2 / 0$ hooks. Although survival was high (98\%) among mouthhooked fish in our study, indicating that hook size is not an important determinant of survival among these fish, our survival estimates for esophagus-hooked fish may be sensitive to hook size (e.g., Weidlein 1987). Based on Weidlein's (1987) results for hooks of different sizes, our survival estimates are possibly a bit conservative (too low). Finally, hook configuration (single versus treble hooks) may affect survival (Muoneke and Childress 1994); however, we conducted experiments with treble hooks of various sizes (G.R.W. and K.L.P., unpublished data) and found no relationship between postrelease survival of largemouth bass and the number of hook wounds caused by treble hooks.

Our model provides direction for future studies of fish survival after catch-and-release episodes. In general, there exists a lack of conceptualization in previous studies of fish survival. We believe that future studies would benefit from explicitly stated conceptual models of survival that are rigorously tested with thoughtful hypotheses. This approach should minimize conflicting results and provide more advanced knowledge of factors affecting fish survival.

\section{Acknowledgments}

We thank Susan Pope and Connie Wilde for allowing us to use household monies to fund this research and Bass Pro Shops for the donation of terminal tackle used in this study. We thank Tanya and Malcolm Thomas for providing access to fish at the Aught-Four Ranch and Texas Parks and Wildlife Department personnel for aid in collecting some of the largemouth bass used in this study. We are grateful to Christopher J. Chizinski, Wilfrido M. ContrerasSánchez, James F. Dumbald, Bart W. Durham, Caleb G. Huber, Guadalupe Morales Lara, Felix Martinez, Jr., Salomón Páramo, Jessica L. Pope, Kody L. Pope, Jesse P. Shuck, and Gregory Wilde for volunteering their assistance in the laboratory and field and to Wayne A. Hubert and Craig P. Paukert for commenting on the manuscript.

\section{References}

Bartholomew, A., and J. A. Bohnsack. 2005. A review of catch-and-release angling mortality with implications for no-take reserves. Reviews in Fish Biology and Fisheries 15:129-154.

Cooke, S. J., and W. J. Hogle. 2000. Effects of retention gear on the injury and short-term mortality of adult smallmouth bass. North American Journal of Fisheries Management 20:1033-1039.

Cooke, S. J., J. F. Schreer, D. H. Wahl, and D. P. Philipp. 2002. Physiological impacts of catch-and-release angling practices on largemouth bass and smallmouth bass. Pages 489-512 in D. P. Philipp and M. S. Ridgway, editors. Black bass: ecology, conservation, and management. American Fisheries Society, Symposium 31, Bethesda, Maryland.

Davis, M. W. 2002. Key principles for understanding fish bycatch discard mortality. Canadian Journal of Fisheries and Aquatic Sciences 59:1834-1843.

Diggles, B. K., and I. Ernst. 1997. Hooking mortality of two species of shallow-water reef fish caught by recreational angling methods. Marine and Freshwater Research 48:479-483.

Dunmall, K. M., S. J. Cooke, J. F. Schreer, and R. S. McKinley. 2001. The effect of scented lures on the hooking injury and mortality of smallmouth bass caught by novice and experienced anglers. North American Journal of Fisheries Management 21:242-248.

Edwards, G. P., Jr., R. M. Neumann, R. P. Jacobs, and E. B. O'Donnell. 2004. Factors related to mortality of black bass caught during small club tournaments in Connecticut. North American Journal of Fisheries Management 24:801-810.

Hartley, R. A., and J. R. Moring. 1993. Observations of black bass (Centrarchidae) confined during angling tournaments: a cautionary note concerning dissolved oxygen. Aquaculture and Fisheries Management 24:575-579.

Hulbert, P. J., and R. Engstrom-Heg. 1980. Hooking mortality of worm-caught hatchery brown trout. New York Fish and Game Journal 27:1-9.

James, J. T., G. W. Stunz, D. A. McKee, and R. R. Vega. 
2007. Catch-and-release mortality of spotted seatrout in Texas: effects of tournaments, seasonality, and anatomical hooking location. North American Journal of Fisheries Management 27:900-907.

Killen, S. S., C. D. Suski, S. J. Cooke, D. P. Philipp, and B. L. Tufts. 2006. Factors contributing to the physiological disturbance in walleyes during simulated live-release angling tournaments. Transactions of the American Fisheries Society 135:557-569.

Kwak, T. J., and M. G. Henry. 1995. Largemouth bass mortality and related causal factors during live-release fishing tournaments on a large Minnesota lake. North American Journal of Fisheries Management 14:621-630.

Lindsay, R. B., R. K. Schroeder, K. R. Kenaston, R. N. Toman, and M. A. Buckman. 2004. Hooking mortality by anatomical location and its use in estimating mortality of spring Chinook salmon caught and released in a river sport fishery. North American Journal of Fisheries Management 24:367-378.

Mankin, P. C., D. P. Burkett, P. R. Beaty, W. F. Childers, and D. P. Philipp. 1984. Effects of population density and fishing pressure on hook-and-line vulnerability of largemouth bass. Transactions of the Illinois State Academy of Science 77:229-240.

May, B. E. 1973. Evaluation of largescale release programs with special reference to bass fishing tournaments. Proceedings of the Annual Conference Southeastern Association of Game and Fish Commissioners 26(1972):325-334.

Muoneke, M. I., and W. M. Childress. 1994. Hooking mortality: a review for recreational fisheries. Reviews in Fisheries Science 2:123-156.

Myers, R. A., and S. M. Poarch. 2002. Effects of bait type and hooking location on post-release mortality of largemouth bass. Proceedings of the Annual Conference Southeastern Association of Fish and Wildlife Agencies 54(2000):39-45.

Nelson, K. L. 1998. Catch-and-release mortality of striped bass in the Roanoke River, North Carolina. North American Journal of Fisheries Management 18:25-30.

Nuhfer, A. J., and G. R. Alexander. 1992. Hooking mortality of trophy-sized wild brook trout caught on artificial lures. North American Journal of Fisheries Management 12:634-644.

Pelzman, R. J. 1978. Hooking mortality of juvenile largemouth bass, Micropterus salmoides. California Fish and Game 64:185-188.

Plumb, J. A., J. M. Grizzle, and W. A. Rogers. 1988. Survival of caught and released largemouth bass after confinement in live wells. North American Journal of Fisheries Management 8:325-238.

Pope, K. L., and G. R. Wilde. 2004. Sublethal effects of catchand-release fishing on largemouth bass. Fisheries Management and Ecology 11:39-44.

Pope, K. L., and D. W. Willis. 1996. Seasonal influences on freshwater fisheries sampling data. Reviews in Fisheries Science 4:57-73.

Prentice, J. A., J. L. Hernandez, C. E. Shaw, and R. W. Wienecke. 1993. Rapid placement and retention of passive integrated transponder (PIT) tags in grass carp.
Proceedings of the Annual Conference Southeastern Association of Fish and Wildlife Agencies 45(1991):415-421.

Roy Morgan Research. 2003. Released fish survival national survey report. Roy Morgan Research, Melbourne, Australia.

Rutledge, W. P., and D. L. Pritchard. 1977. Hooking mortality of largemouth bass captured by artificial lures and natural bait. Pages 103-107 in R. A. Barnhart and T. D. Roelofs, editors. Catch-and-release fishing as a management tool. Humboldt State University, Arcata, California.

Schill, D. J., J. S. Griffith, and R. E. Gresswell. 1986. Hooking mortality of cutthroat trout in a catch-and-release segment of the Yellowstone River, Yellowstone National Park. North American Journal of Fisheries Management 6:226-232.

Stunz, G. W., and D. A. McKee. 2006. Catch-and-release mortality of spotted seatrout in Texas. North American Journal of Fisheries Management 26:843-848.

Suski, C. D., S. J. Cooke, S. S. Killen, D. H. Wahl, D. P. Philipp, and B. L. Tufts. 2005. Behaviour of walleye, Sander vitreus, and largemouth bass, Micropterus salmoides, exposed to different wave intensities and boat operating conditions during livewell confinement. Fisheries Management and Ecology 12:19-26.

Suski, C. D., S. S. Killen, S. J. Cooke, J. D. Kieffer, D. P. Philipp, and B. L. Tufts. 2004. Physiological significance of the weigh-in during live-release angling tournaments for largemouth bass. Transactions of the American Fisheries Society 133:1291-1303.

Taylor, M. J., and K. R. White. 1992. A meta-analysis of hooking mortality of nonanadromous trout. North American Journal of Fisheries Management 12:760-767.

Taylor, R. G., J. A. Whittington, and D. E. Haymans. 2001. Catch-and-release mortality rates of common snook in Florida. North American Journal of Fisheries Management 21:70-75.

USFWS and USCB (U.S. Fish and Wildlife Service and U.S. Census Bureau). 2002. 2001 National survey of fishing, hunting, and wildlife-associated recreation. USFWS and USCB, Washington, D.C.

Weidlein, W. D. 1987. Mortality of released sublegal-sized smallmouth bass, catch-and-release implications. Pages 217-228 in R. A. Barnhart and T. D. Roelofs, editors. Catch-and-release fishing: a decade of experience. Humbolt State University, Arcata, California.

Wilde, G. R. 1998. Tournament-associated mortality in black bass. Fisheries 23(10):12-22.

Wilde, G. R., M. I. Muoneke, P. W. Bettoli, K. L. Nelson, and B. T. Hysmith. 2000. Striped bass hooking mortality in freshwater. North American Journal of Fisheries Management 20:809-814.

Wilde, G. R., K. L. Pope, and B. W. Durham. 2003a. Lure size restrictions in recreational fisheries. Fisheries 28(6):1826.

Wilde, G. R., K. L. Pope, and R. E. Strauss. 2003b. Estimation of fishing-tournament mortality and its sampling variance. North American Journal of Fisheries Management 23:779-786. 